\title{
SERISHM: AN ECO-FRIENDLY AND BIODEGRADABLE FLAME RETARDANT FOR FABRICS
}

\author{
Sayyed Mahdi Hejazi ${ }^{1,2^{*}}$, Fahimeh Lotfi ${ }^{1}$, Hossein Fashandi ${ }^{3}$, Azam Alirezazadeh ${ }^{4}$ \\ ${ }^{1}$ Department of Textile Engineering, Isfahan University of Technology, Isfahan 84156-83111, Iran. \\ ${ }^{2}$ Assistant Professor, Department of Textile Engineering, Isfahan University of Technology, Isfahan 84156-83111, Iran. \\ ${ }^{3}$ Assistant Professor, Department of Textile Engineering, Isfahan University of Technology, Isfahan 84156-83111, Iran. \\ ${ }^{4}$ Master of Science, Department of Textile Engineering, Isfahan University of Technology, Isfahan 84156-83111, Iran. \\ *Corresponding author email: hejazi110@cc.iut.ac.ir
}

This is an open access article distributed under the Creative Commons Attribution License, which permits unrestricted use, distribution, and reproduction in any medium, provided the original work is properly cited.

\section{ARTICLE DETAILS}

\section{Article History:}

Received 2 July 2017

Accepted 3 October 2017

Available online 2 November 2017

\section{Keywords:}

Eco-friendly,

Biodegradable, Flame retardant, Fabric, Serishm.

\begin{abstract}
Biodegradable and eco-friendly materials are preferred due to less environmental impacts in compare to synthetic and chemical compounds. Serishm is known as a natural protein based material which includes Collagen and has been considered as an ancient coating on textile materials. However, there is a lack of scientific approach and experimental finding to show the capability of using this material as the fire retardant for fabrics. Therefore, the main objective of this work is to investigate the possibility of using Serishm as a natural fire-retardant material. 23 various samples in fabric type (polyester, cotton and cotton/polyester), Serishm content in $150 \mathrm{cc}$ water $(5,10$ and $15 \mathrm{~g}$ ) were investigated under various conditions of padding pressure (2, 3 and $4 \mathrm{MPa})$, padding times $(2,3$ and 4 times $)$ andmethod of coating (pad dry cure, conventional method and injection molding of silicone-resin. Moreover, as cotton fabrics were highly flammable, various nano-silica contents $(2,4$ and $8 \%)$ were used to determine the most appropriate condition for cotton fabrics. Flame retardancy and physical properties of each sample were evaluated. According to the test results, polyester fabric coated by Serishm showed better flame retardancy in compare to cotton and cotton/polyester fabrics. By increasing the padding times, the sample was capable to stop the firing procedure. The conventional coating showed better results in compare to padding methods, while the injection molding was the most appropriate method in compare to the other methods. It was concluded that the protein resin could completely penetrate into the fabric texture during injection molding. Therefore, by applying Serishm through injection method even cotton fabrics showed better flame retardancy.
\end{abstract}

\section{INTRODUCTION}

Nowadays, the main environmental concerns are due to the production and utilization of chemical compounds more than ever before [1-5]. Flame-retardants (FR) are considered as a group of anthropogenic environmental contaminants as well as heavy metals [6] which are widely used in many applications [7]. Many researchers have focused on the concentrations [8] and effects of chemical compounds such as brominated [9], organo-phosphorus flame retardants [10] and many others on human health, environment and indoor air [11]. Additionally, some other researchers have focused on using biodegradable and eco-friendly compounds to be used as the flame retardant materials.

In compare to synthetic and chemical compounds, biodegradable and ecofriendly materials are preferred due to less environmental impacts. Sharma et al $[12,13]$ have compared various eco-friendly methods of flame retardant treatments of cellulose-based materials and indicated that there is still the need of developments in this case. Most of previous research studies have focused on hazards of using flame retardants but less .works have been done in the case of introducing green flame retardants Therefore, the main objective of the present work is to investigate the capability of using a green material as a suitable fire retardant for fabrics. Serishm is an ancient animal based material which was mostly used as a binder of fabric/wood in paintings for many years ago [14], and laterally was replaced by the conventional white wood glue. It is mainly made from a protein based material including Collagen. Collagen is basically a biodegradable and natural protein derived from animals and fishes [15]. However, there is a lack of scientific experimental results to show the capability of using this material as the natural fire retardant for fabrics. Therefore, in the present work with the aim of introducing a biodegradable and eco-friendly material such as Serishm, the possibility of using this material in flame retardant applications such as textile fabrics was investigated.

\section{MATERIALS AND METHODS}

First of all, Fourier Transform Infrared Spectroscopy (FTIR) analysis was carried out on Serishm powder. The Serishm powder was mixed by $\mathrm{KBr}$ powder and was pressed carefully to be in appropriate dimension for FTIR test. By changing some factors affecting flame retardancy 23 samples were fabricated in order to investigate the possibility of using Serishm as a natural flame retardant coating for fabrics. The following independent variables were selected which could affect the flame retardancy:

1- Fabric type (polyester, cotton and cotton/polyester)

2 - Serishm content in $150 \mathrm{cc}$ water $(5,10$ and $15 \mathrm{~g})$

3- Pad pressure (2, 3 and $4 \mathrm{MPa})$

4- Padding times (2, 3 and 4 times)

5- Method of coating (pad dry cure, conventional method and injection molding of silicone-resin)

6- Nano-silica content for cotton fabrics $(2,4$ and $8 \%)$

The flame spread time, fired area and the self-extinguishing ability were considered as the response variables. Fire retardancy of each sample was investigated through edge and surface ignition tests.

The effects of Serishm contents and fabric type were investigated at the pad pressure of $2 \mathrm{MPa}$, Stenter temperature of $100^{\circ} \mathrm{C}$ and curing time of 2 minutes. Baking procedures were carried out on cotton, polyester and cotton/polyester fabrics at the temperatures of 130,150 and $170^{\circ} \mathrm{C}$ up to 5,3 and 1 minutes, respectively.

The effects of Stenter pressure on cotton fabric were investigated at the Serishm contents of 10 grams per $150 \mathrm{cc}$ water, drying temperature of $100^{\circ} \mathrm{C}$ and baking temperature of $130^{\circ} \mathrm{C}$ up to 5 minutes.

The padding procedure was carried out on all types of fabrics for 4 times to investigate the effects of padding times. 
The samples characteristics are presented in table 1.

Table 1: Samples characteristics

\begin{tabular}{|c|c|c|c|}
\hline \multirow{10}{*}{$\begin{array}{c}\text { Effects of fabric } \\
\text { type }\end{array}$} & $\begin{array}{l}\text { Sample } \\
\text { No. }\end{array}$ & Fabric type & $\begin{array}{l}\text { Serishm } \\
\text { (gr in } 150 \\
\text { cc water) }\end{array}$ \\
\hline & 1 & Polyester & 5 \\
\hline & 2 & Polyester & 10 \\
\hline & 3 & Polyester & 15 \\
\hline & 4 & Cotton/Polyester & 5 \\
\hline & 5 & Cotton/Polyester & 10 \\
\hline & 6 & Cotton/Polyester & 15 \\
\hline & 7 & Cotton & 5 \\
\hline & 8 & Cotton & 10 \\
\hline & 9 & Cotton & 15 \\
\hline \multirow{4}{*}{$\begin{array}{l}\text { Effects of Nano- } \\
\text { silica content on } \\
\text { cotton fabrics }\end{array}$} & $\begin{array}{l}\text { Sample } \\
\text { No. }\end{array}$ & $\begin{array}{c}\text { Serishm+ } \\
\text { Nanosilis (\%) }\end{array}$ & $\begin{array}{l}\text { Serishm } \\
\text { (gr in 150 } \\
\text { cc water) }\end{array}$ \\
\hline & 10 & 2 & 10 \\
\hline & 11 & 4 & 10 \\
\hline & 12 & 8 & 10 \\
\hline \multirow{4}{*}{$\begin{array}{c}\text { Effects of } \\
\text { Stenter pressure }\end{array}$} & $\begin{array}{l}\text { Sample } \\
\text { No. }\end{array}$ & $\begin{array}{l}\text { Stenter Pressure } \\
\text { (MPa) }\end{array}$ & $\begin{array}{l}\text { Serishm } \\
\text { (gr in 150 } \\
\text { cc water) }\end{array}$ \\
\hline & 13 & 2 & 10 \\
\hline & 14 & 3 & 10 \\
\hline & 15 & 4 & 10 \\
\hline \multirow{4}{*}{$\begin{array}{c}\text { Effects of } \\
\text { padding times }\end{array}$} & $\begin{array}{l}\text { Sample } \\
\text { No. }\end{array}$ & Fabric Type & $\begin{array}{l}\text { Serishm } \\
\text { (gr in 150 } \\
\text { cc water) }\end{array}$ \\
\hline & 16 & Polyester & 10 \\
\hline & 17 & Cotton & 10 \\
\hline & 18 & Cotton/Polyester & 10 \\
\hline \multirow{4}{*}{$\begin{array}{l}\text { Effects of } \\
\text { conventional } \\
\text { resin coating } \\
\text { method }\end{array}$} & $\begin{array}{l}\text { Sample } \\
\text { No. }\end{array}$ & Fabric Type & $\begin{array}{c}\text { Serishm } \\
\text { (gr in } 150 \\
\text { cc water) }\end{array}$ \\
\hline & 19 & Cotton & 10 \\
\hline & 20 & Cotton/Polyester & 10 \\
\hline & 21 & Polyester & 10 \\
\hline \multirow{3}{*}{$\begin{array}{c}\text { Effects of } \\
\text { injection } \\
\text { molding of } \\
\text { silicon-Serishm } \\
\text { method }\end{array}$} & $\begin{array}{l}\text { Sample } \\
\text { No. }\end{array}$ & Fabric Type & $\begin{array}{l}\text { Serishm } \\
\text { (gr in 150 } \\
\text { cc water) }\end{array}$ \\
\hline & 22 & Polyester & 10 \\
\hline & 23 & Cotton & 10 \\
\hline
\end{tabular}

Afterwards, the physical properties of samples such as thickness (ASTM D1777), flexural rigidity (ASTM D1388) and permeability (ASTM D737) were investigated at the standard condition of $20^{\circ} \mathrm{C}$ and R.H. Of $65 \%$ by a set of testing devices in Isfahan University of Technology Lab., as shown in Figure 1.

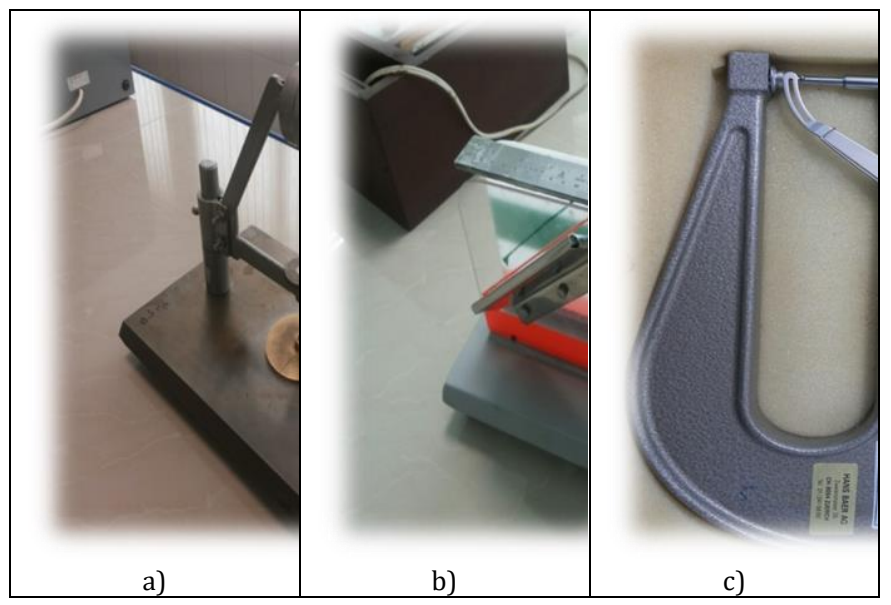

Figure 1: a) Thickness test device b) Flexural rigidity test device c) Permeability test device

After being treated by Serishm, the samples were investigated through edge and surface ignition tests, as shown in Figure 2.

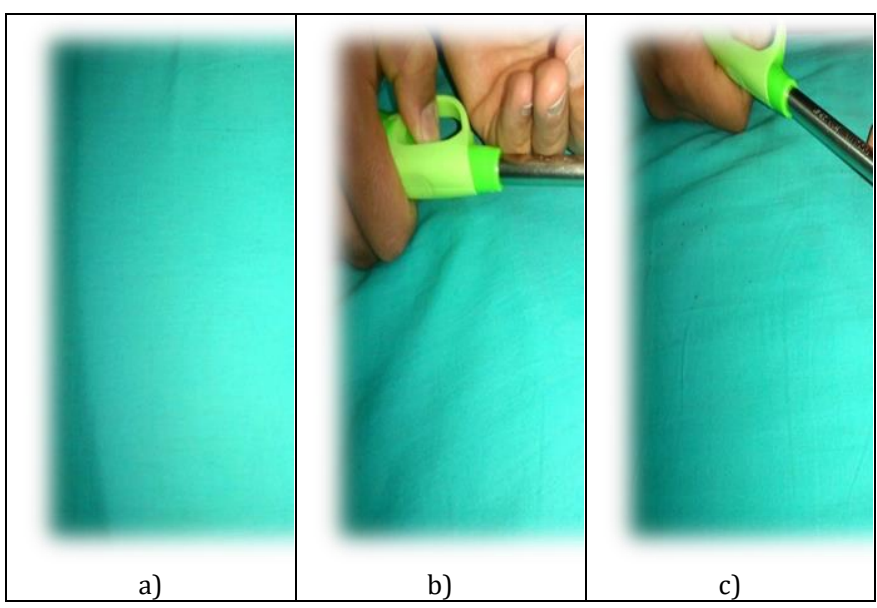

Figure 2: a) Sample 16 exposed to flame during edge ignition tests b) Sample 19 exposed to flame during surface ignition test c) Sample 22 exposed to flame during edge ignition test

\section{RESULTS AND DISCUSSION}

The results of FTIR analysis are presented in figure 7.

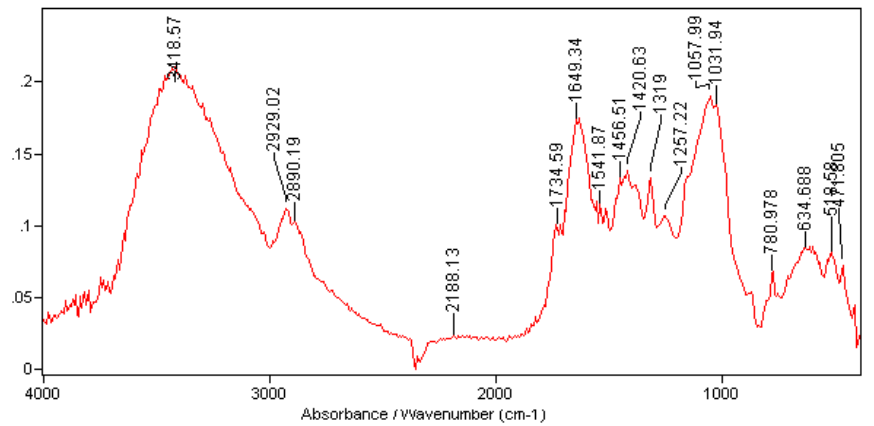

Figure 7: FTIR analysis of Serishm

The wavelengths of peak absorption were $3418.57 \mathrm{~nm}$ for $\mathrm{N}-\mathrm{H}$ or $\mathrm{O}-\mathrm{H}$ bonds, 2929.02 and $2890.19 \mathrm{~nm}$ for C-H bonds, $2188.13 \mathrm{~nm}$ for presence of $\mathrm{CO} 2$ in air, $1734.59 \mathrm{~nm}$ for $\mathrm{C}=0$ bonds, $1649.34 \mathrm{~nm}$ for amide bonds and $1257.22 \mathrm{~nm}$ for C-O bonds. Therefore, Serishm is considered as a protein based material including amide bonds and amino acids.

The results of physical properties and fire retardancy tests are presented in table 2 .

Table 2: the physical properties and results of fire retardancy tests for each sample

\begin{tabular}{|c|c|c|c|c|c|c|c|}
\hline \multirow[b]{2}{*}{$\begin{array}{l}\text { Sam } \\
\text { ple } \\
\text { No. }\end{array}$} & \multicolumn{2}{|c|}{$\begin{array}{c}\text { Surface } \\
\text { ignition test }\end{array}$} & \multicolumn{2}{|c|}{$\begin{array}{c}\text { Edge ignition } \\
\text { test }\end{array}$} & \multirow{2}{*}{$\begin{array}{c}\text { Air } \\
\text { permea } \\
\text { bility } \\
\text { (ml/se } \\
\text { c) }\end{array}$} & \multirow{2}{*}{$\begin{array}{l}\text { Flex } \\
\text { ural } \\
\text { rigid } \\
\text { ity } \\
(\mathrm{cm})\end{array}$} & \multirow[b]{2}{*}{$\begin{array}{c}\text { Thick } \\
\text { ness } \\
(\mathrm{mm})\end{array}$} \\
\hline & $\begin{array}{l}\text { Self- } \\
\text { extingu } \\
\text { ished }\end{array}$ & $\begin{array}{l}\text { Fir } \\
\text { ed } \\
\text { ar } \\
\text { ea }\end{array}$ & $\begin{array}{l}\text { Self- } \\
\text { extingu } \\
\text { ished }\end{array}$ & $\begin{array}{l}\text { Fir } \\
\text { ed } \\
\text { ar } \\
\text { ea }\end{array}$ & & & \\
\hline 1 & - & - & - & - & $\begin{array}{l}\text { Very } \\
\text { high }\end{array}$ & 4.7 & 0.27 \\
\hline 2 & - & - & - & - & $\begin{array}{l}\text { Very } \\
\text { high }\end{array}$ & 4.1 & 0.28 \\
\hline 3 & - & - & - & - & $\begin{array}{l}\text { Very } \\
\text { high }\end{array}$ & 6.2 & 0.29 \\
\hline 4 & - & - & - & - & 95 & 3.7 & 0.27 \\
\hline 5 & - & - & - & - & 85 & 3.3 & 0.28 \\
\hline 6 & - & - & - & - & 75 & 3.1 & 0.29 \\
\hline 7 & - & - & - & - & 200 & 7.0 & 0.32 \\
\hline 8 & - & - & - & - & 100 & 7.2 & 0.34 \\
\hline 9 & - & - & - & - & 150 & 7.3 & 0.40 \\
\hline 10 & - & - & - & - & 135 & 5.6 & 0.32 \\
\hline 11 & - & - & - & - & 130 & 4.0 & 0.35 \\
\hline 12 & - & - & - & - & 110 & 3.5 & 0.35 \\
\hline 13 & - & - & - & - & 155 & 8.5 & 0.35 \\
\hline 14 & - & - & - & - & 180 & 7.6 & 0.35 \\
\hline 15 & - & - & - & - & 190 & 6.1 & 0.40 \\
\hline 16 & - & - & yes & $\begin{array}{l}30 \\
\%\end{array}$ & 110 & 6.5 & 0.25 \\
\hline 17 & - & - & - & - & 145 & 8.0 & 0.40 \\
\hline
\end{tabular}




\begin{tabular}{|c|c|c|c|c|c|c|c|}
\hline 18 & - & - & - & - & 80 & 5.8 & 0.29 \\
\hline 19 & - & - & yes & $\begin{array}{l}20 \\
\%\end{array}$ & - & - & 0.93 \\
\hline 20 & - & - & - & - & - & - & 0.92 \\
\hline 21 & yes & $\begin{array}{l}60 \\
\%\end{array}$ & yes & $\begin{array}{l}10 \\
\%\end{array}$ & - & - & 0.81 \\
\hline 22 & yes & $\begin{array}{c}1 \\
\%\end{array}$ & yes & $\begin{array}{l}20 \\
\%\end{array}$ & - & 5.0 & 0.54 \\
\hline 23 & yes & $\begin{array}{c}1 \\
\% \\
\end{array}$ & - & - & - & 5.2 & 0.76 \\
\hline
\end{tabular}

Figures 3 and 4 show the results of edge and surface ignition tests, respectively.

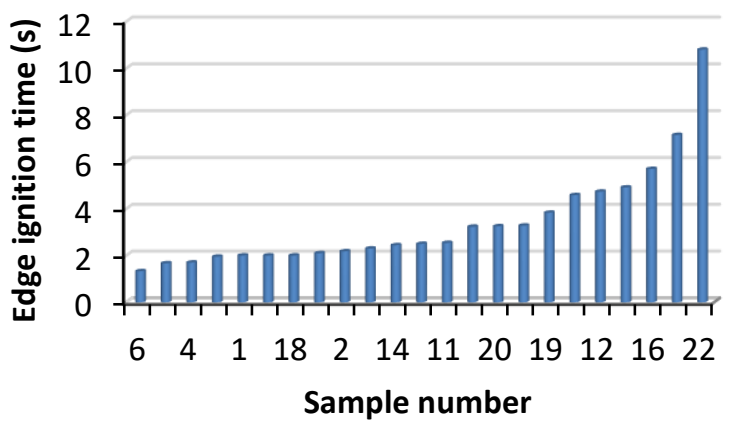

Figure 3: comparing the edge ignition time

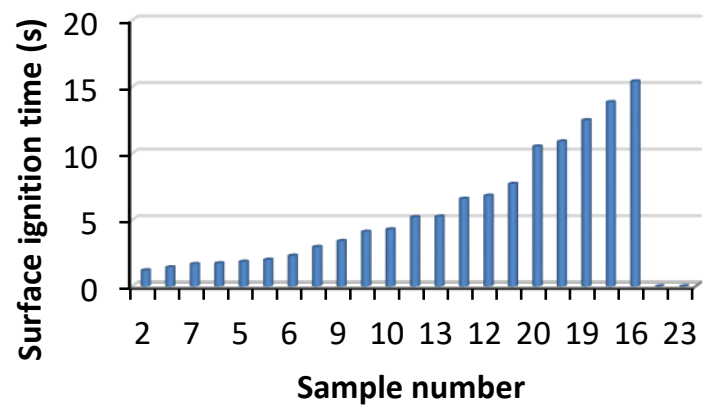

Figure 4: Comparing the surface ignition time

SPSS v16.0 software was used to investigate the homogeneity of variances in comparing means. As shown in tables 4 and 5 , the Sig. value $<0.05$ indicates the homogeneity of variances.

Table 4: Test of Homogeneity of Variances in comparing means of edge ignition time

\begin{tabular}{cccc}
\hline Levene Statistic & df1 & df2 & Sig. \\
\hline 1.233 & 22 & 46 & .269 \\
\hline
\end{tabular}

Table 5: Test of Homogeneity of Variances in comparing means of surface ignition time

\begin{tabular}{cccc}
\hline Levene Statistic & df1 & df2 & Sig. \\
\hline 1.679 & 22 & 46 & .069 \\
\hline
\end{tabular}

According to the results, samples 22 and 23 did not show any significant change after being exposed to flame. Therefore, the flame retardancy extremely depends on the method of treatment. However, by increasing the amount of resin on fabric, the thickness increases while reducing the flexural rigidity and permeability. Although cotton fabric is highly flammable, by applying Serishm through injection molding, a flame retardant fabric is achieved. Totally, it is concluded that coating polyester fabrics by Serishm through injection molding method offers a suitable flame retardant material. Therefore, Serishm as a biodegradable and natural flame retardant which has no serious impacts on environment can be used instead of synthetic resins.

\section{CONCLUSION}

Biodegradable and eco-friendly materials are preferred due to less environmental impacts in compare to synthetic and chemical compounds. Serishm is considered to be a protein based material and a suitable fire retardant for fabrics. However, there is a lack of scientific experimental results to show the capability of using this material as the fire retardant for fabrics. Therefore, in this work, 23 various samples in fabric type, Serishm content and nano-silica content were investigated under various conditions of pad pressure, padding times and method of coating. Flame retardancy and physical properties of each sample were evaluated. According to test results, polyester fabric coated by Serishm showed better flame retardancy in compare to cotton and cotton/polyester fabrics. By increasing the padding times, the sample was capable to stop the firing procedure. The conventional coating method showed better results in compared to padding method. However, by increasing the amount of resin on fabric, the thickness increases while reducing the flexural rigidity and permeability.

The flame retardancy extremely depends on the method of treatment. Although cotton fabric is highly flammable, by applying Serishm through injection molding, a flame retardant fabric is achieved. It was concluded that the protein resin penetrates completely into the fabric texture during injection molding. Hence, by applying Serishm through injection method even cotton fabrics showed better flame retardancy.

Totally, it is concluded that coating polyester fabrics by Serishm through injection molding method offers a suitable flame retardant material. Therefore, Serishm as a biodegradable and natural flame retardant which has no serious impacts on environment can be used instead of synthetic resins. As the flame retardant treatment increased the flexural rigidity and the thickness of fabrics, the authors suggest using softener and investigate other aspects of this work for future.

\section{REFERENCES}

[1] Ali, N., Shahzad, K., Rashid, M.I., Shen, H., Ismail, I.M.I., Eqani, S.A.M.A.S. 2017. Currently used organophosphate and flame retardants in the environment of China and other developing countries (2000-2016). Environmental Science and Pollution Research, 1-21. doi: 10.1007/s11356-017-9336-3.

[2] Fromme, H., Lahrz, T., Kraft, M., Fembacher, L., Mach, C., Dietrich, S., Burkardt, R., Volkel, W., Goen, T. 2014. Organophosphate flame retardants and plasticizers in the air and dust in German daycare centers and human bio monitoring in visiting children (LUPE 3). Environment International, $71,158-163$.

[3] Cristale, J., Vazquez, A.G., Barata, C., Lacorte, S. 2013. Priority and emerging flame retardants in rivers: Occurrence in water and sediment, Daphnia magna toxicity and risk assessment. Environment International, 59, 232-243.

[4] Cruz, R., Cunha, S.C., Casal, S. 2015. Brominated flame retardants and seafood safety: A review. Environment International, 77, 116-131.

[5] Venier, M., Audy, O., Vojta, S., Becanova, J., Romanak, K., Melymuk, L., Kratka, M., Kukucka, P., Okeme, J., Saini, A., Diamond, M.L., and Klanova, J. 2016. Brominated flame retardants in the indoor environmentComparative study of indoor contamination from three countries. Environment International, 94, 150-160.

[6] Azratul, A.N.M.D., Akbar-John, B., Kamaruzzaman, B.Y., Sheikh, H.I., Jalal, K.C.A., Noor-Faizul, H.N. 2017. Biomonitoring Selected Heavy Metal Concentration in Nerita Sp. Collected from Tanjung Lumpur Mangrove Forest. Environment and Ecosystem Science, 1(1), 04-07.

[7] Segev, O., Kushmaro, A., Brenner, A. 2009. Environmental Impact of Flame Retardants Persistence and Biodegradability. International Journal of Environmental Research and Public Health, 6 (2), 478-491.

[8] Shoeib, M., Ahrens, L., Jantunen, L., and Harner, T. 2014. Concentrations in air of rganobromine, organochlorine and organophosphate flame retardants in Toronto, Canada. Atmospheric Environment, 99, 140-147.

[9] Lyche, J.L., Rosseland, C., Berge, G., and Polder, A. 2015. Human health risk associated with brominated flame-retardants (BFRs). Environment International, 74, 170-180.

[10] Wolschke, H., Sühring, R., Mi, W., M€oller, A., Xie, Z., and Ebinghaus, R. 2016. Atmospheric occurrence and fate of organophosphorus flame 
retardants and plasticizer at the German coast. Atmospheric Environment, 137, 1-5.

[11] Rauert, C., Lazarov, B., Harrad, S., Covaci, A., Stranger, M. 2014. A review of chamber experiments for determining specific emission rates and investigating migration pathways of flame retardants. Atmospheric Environment, 82, 44-55.

[12] Sharma, N.K., Verma, C.S., Chariar, V.M., and Prasad, R. 2013. Ecofriendly flame-retardant treatments for cellulosic green building materials. Indoor and Built Environment, 1-11.
[13] Sharma, N.K., Chariar, V.M., and Prasad, R. 2015. Impact of fire on Dendrocalamus strictus- a natural green composite building material, Indoor and Built Environment, 24 (6), 740-745.

[14] Villers, C. 2000. Four scenes of the Passion painted in Florence around 1400, Country: United Kingdom, Creative Commons Help Search Paper Order Contact Legal Terms of Use Credits. See also URL http://www.openbibart.fr/item/display/10068/780251

[15] Inamuddin. 2017. Green Polymer Composites Technology, Properties and Applications, CRC Press, 517. 